\title{
The Relationship between Network Marketing Organization and the Related Industry Sustainability in Indonesia
}

\author{
Thamrin SELAMET ${ }^{1}$, Harjanto PRABOWO ${ }^{2}$
}

Received: September 01, 2020 Revised: October 26, 2020 Accepted: November 05, 2020

\begin{abstract}
Network marketing in Indonesia, especially in a time of crisis, is massively rising and has become a popular opportunity among other industries. Network marketing organizations, consists of partnership and trust, a community of connections and contact between individuals. This article has tried to examine the potential strategy to mitigate low trust in network marketing organizations specifically in the Indonesia market, where no studies on the subject has been done before. In doing this research assignment employed a secondary research methodology by reviewing previous academic literatures, by exploration and evaluation. For the purpose, 6 main articles and 25 relevant supporting articles were selected, there is an interesting and prominent research in an effort to repair trust in the perspective of the organization's efforts to build trust and control trust framework in strategy trust repair. The result of this analysis showed that the application of trust-building activities studies reveals how trustbuilding behavior is related to controls and how the efforts towards fostering subordinate cooperation are motivated by different types of controls and display of trustworthiness. It can be concluded that by implementing this trust repair model consistently and with a full commitment, it can gradually restore people's trust in the network marketing industry, sustain industry existence and exalted purpose of this industry can be achieved.
\end{abstract}

Keywords: Network Marketing, Trust Repair, Reputation, Potential Strategy, Trustworthiness

JEL Classification Code: L1, M2, M3, N2

\section{Introduction}

Network marketing is a business model that provides a tremendous opportunity for people who want to have a business but lack capital (Sreekumar, 2007), some people called it helping people do business. Network marketing businesses massively continue growth in Indonesia. Along the way, it was found that there were too many violations committed by irresponsible network marketing practitioners, such as conducting pyramid systems, Ponzi schemes, and various fraudulent attempts that undermine the legitimacy of

${ }^{1}$ First Author and Corresponding Author. Management Department, Binus Business School, Bina Nusantara University, Indonesia [Postal Address: The Joseph Wibowo Center Hang Lekir I No. 6, Senayan Jakarta 10270, Indonesia] Email: thamrin.selamet@binus.ac.id

2Management Department, BINUS Business School - Undergraduate

Program, Bina Nusantara University, Indonesia.

Email: harprabowo@binus.edu

(c) Copyright: The Author(s)

This is an Open Access article distributed under the terms of the Creative Commons Attribution Non-Commercial License (https://creativecommons.org/licenses/by-nc/4.0/) which permits unrestricted non-commercial use, distribution, and reproduction in any medium, provided the original work is properly cited. network marketing organizations. Many years have passed by and various deceptive practices in the name of network marketing has caused the global community to lose confidence and trust in this industry (Attri \& Chaturvedi, 2011; Bosley \& McKeage, 2015; Keep \& Nat, 2014; Mathews, Manalel, \& Zacharias, 2007; Moradi, Bavi, \& Pooran, 2013).

Network marketing organizations consist of a group of people interaction and communication through relationship and trust basis. The organization will not do well if the community gradually loses trust (Constantin, 2009; Ivashkova, Sidorchuk, \& Skorobogatykh, 2018). That's why it becomes very serious and important for all network marketing business people to carry out activities and actions to improve the level of trust for the sustainability of this industry (Poon, Albaum, \& Chan, 2012; Salciuviene, Reardon, \& Auruskeviciene, 2011). Trust in organizations was identified as important. In addition, there is a widely recognized theme that trust should go beyond plausible or calculated trust in various forms of social trust. The emerging role of trust takes on its full meaning, as trust is an ideal center for those interested in the dynamics of organizations, as trust is at the threshold of psychology and sociology. For this reason, the study of trust in political science, 
political research, jurisprudence, organizational psychology, organizational behavior, and behavioral economics is important (Tyler, 2003).

Kramer (2012) studied whether the trust in the organization or its leadership is shattered, it can be convalescent or re-establish after the trust damage has been made, and highlight the important point that a presumptive trust, when functioning effectively, should be viewed as a "moderate" or disciplined trust. Trusts can serve to maintain a level of trust that is firmly anchored in existing evidence or depending on how appropriate or justified the trust is. To be truly adaptable and creative, our trust expectations must always be calibrated to be environmentally friendly or "fit", in which they are embodied. Trust is crucial in developing long-standing and value-added relationships as it is an important component in improving internal relationships (Ozmen, 2018).

Gaining trust is very important for all salespeople, industries, and consumers because trust facilitates an exchange relationship while distrust prevents it. Aggressiveness, sales orientation, and money-minded attitude also considered as an obstruction in building consumer trust. As a result, having a valid trust measure is very important to ensure that a positive exchange relationship (Poon et al., 2012). What is a trust? Trust is an assessment of confidence on another (a person, group, organization or system) based on positive expectations of future behavior (Hurley et al., 2013), trust is a process and individuals' interaction between each other is an exchange process (Häkkinen, 2012). Trust is important and crucial (Lee \& Loi, 2016) because of a strong desire to understand how to create effective cooperation in organizations. Trust is the key because it allows collaboration. While cooperation is always important in organizations, consumer trust is a crucial factor affecting network marketing business-building activities (Poon et al., 2012).

Throughout the interactions and dyadic relationship between participants, building the trust among two or more separate actors within an organization grows. Trust as a mechanism is very fragile and can be lost much faster than created, and for that purpose, it seems much harder to repair (Häkkinen, 2012). The trust repair literature explores a variety of concrete and symbolic strategies used by organizations to repair trust: apology; denial; promises; explanations; accounts; restructuring; penance; compensation; laws, regulations, and controls; cultural reforms (Bozic et al., 2019; Long, 2018; Mehta et al., 2020; Tomlinson \& Mayer, 2016). Business strategy is an essential point in wading through competition and even innovation itself, including procedures in increasing competition (Firman, Putra, Mustapa, \& Ilyas, 2020).

The imperative of economic growth and sustainable development policy must become technological modernization and digitalization of basic industries enterprises, implementation of investment projects focused on resource-efficient usage of raw materials potentials, creation of new knowledge-intensive industries, fields of activities, and increase of labor efficiency (Nurlanova et al., 2020). In the marketing literature, it is realized that risk perception directly affects purchase and purchase intent, that is when consumers perceive high risks, they are less likely to purchase or buy back online (Tham, Dastane, \& Johari, 2019). The internet is developing at a fast speed globally because of its increased availability, usability and its ability to transfer information, products and services (J. W. Lee et al., 2015). Internet websites and social media have not only ended the age of one-way communication but also put extreme pressure on businesses to engage constituents in unprecedented ways. One things is clear that the internet and social media has changed the balance of power in the consumer's favor and this change has come about quickly (Lee \& Kwag, 2017).

This article tried to address the key question about the potential strategy to mitigate low trust in the network marketing organization specifically in the Indonesia market, which is no study about this case before.

\section{Methodology}

This research was done by the qualitative research; according to Sugiyono, Qualitative research is a research by qualitative which means to collect and analyze the data in forms of word not numeral (Sugiyono, 2016). A Descriptive approach is used to describe the problem of analysis.

This research assignment employed a secondary research methodology by reviewing previous academic literature related to the topic of trust repair and network marketing. The secondary method applied such as searching for research articles through the website of sciencedirect.com and Scopus web with the support of publish or perish software because of its reliable credibility. By using the keywords "network marketing", "trust" and "organization", we got 41 research articles from science direct with years ranging from 2015 2020, 4 research articles were searched by using the keyword "trustworthy organization" and 40 research articles were derived from Scopus through publish.

After the articles were collected, it was explored and evaluated by the result, content and by the topic which appeared to be most interesting for the research purpose. Finally, 6 main articles and 25 relevant supporting articles were selected to be processed as research data.

\section{Results and Discussion}

The highlight of this research was that it did not examine the leadership dimension for improving trust, however it was made very comprehensive as the reputation of network marketing is damaged by the practice of pyramid (Ivashkova et al., 2018; Koroth, 2012; Lee \& Loi, 2016; Reingewerts, 2016) and Ponzi schemes (Lee \& Loi, 2016) that are more inclined to fraudulent practices. 
According to the related literature, Trust repair is a variety of symbolic and practical reparation techniques used by organizations: apologies; negations; promising; accounting; restructuring; penance; compensation; institutional reform; public inquiries; the posting of hostages and the use of third parties certification, memberships, affiliations, and endorsements (Bozic et al., 2019). Tomlinson \& Mayer (2016) proposed how trust and trustworthiness can be repaired by attempting to change different identification measurements and specific emotional reactions using each of these accounts such as denial, excuse, apology, and justification, the literature includes information on trust reparations.

There is an interesting and prominent research in an effort to repair trust in the perspective of the organization's efforts to build trust and control trust framework in strategy trust repair proposed by Long (2018) which obtained a method to control and build trust by establishing desired cooperation from subordinates and by applying control on them in order to demonstrate the trustworthiness. The model is shown in the Figure 1 below, the study explains how managers interpret control activities as interrelated organizational values and demonstrate their trust. Figure 1 also indicates that while this might be able to characterize the views of subordinates on the nature of control trust and in specific terms, managers did not seem to conceive of control applications and displays of legitimacy as a set of dualities, but as distinct categories of activities to encourage subordinate cooperation.

Three relationships identified in this study are very identical with the nature and conditions in network marketing organizations. The implementation of results control leaders mediates the interaction between their motivation and their displays of reliability to inspire superior-subordinate task coordination. The deployment of action controls by leadership mediates the relationship between their aim to encourage subordinate task participation and evidence of competence. The use of personnel control by leaders mediates the relationship between their ability to foster healthy interpersonal relationships and they demonstrate benevolence.

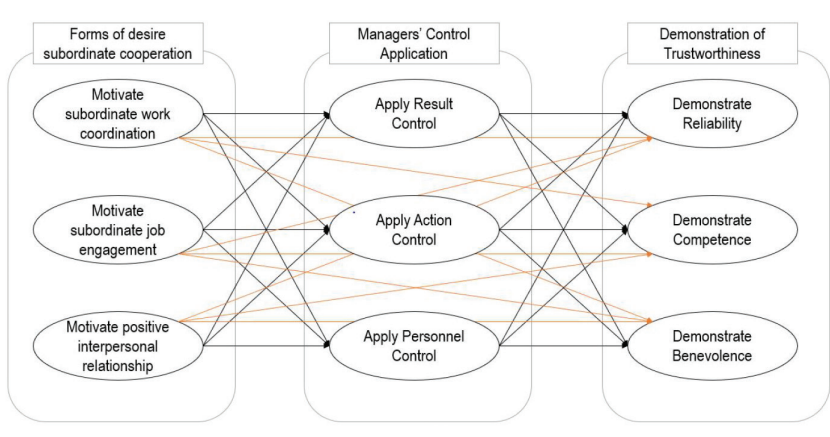

Figure 1: Adapted from Long (2018)
Application of observations of trust-building activities, show off how trust-building behavior is related to controls and explain how the effort to promote subordinate cooperation is motivated by particular types of controls and displays of trustworthiness (Long, 2018). Furthermore, the models explained as the diagram below:

According to Möllering, Bachmann, and Lee (2004), trust consists of three dimensions: cognitive trust, affective trust, and behavior trust. Cognitive trust represents the rational dimensions of an individual's character such as competency, honesty, credibility, and mutual dependence.

Affective trust also known as emotional trust is based on an individual's behavior, like taking care of each other; commitment is also classified as emotional trust. Affective trust is characterized by feelings of security and the perceived strength of the relationship between the consumer and the salesperson. Within the non-western network marketing industry, affective trust is much more critical than the cognitive trust. It is necessary to enhance customer feelings of care, concern, and trustworthiness. Behavior trust is expressed through the effectiveness and commitment toward organization (Poon et al., 2012). Furthermore, Poon et al. (2012) indicated that at least two factors of building up a consumer-salesperson trust are more difficult in the context of network marketing. Firstly, because sales people are independent distributors or contractors, and not the company's staff, and there is no set business location for presenting goods and performing transactions, perceived risk and ambiguity is high. Secondly, commission-based pay drives salespeople to work harder, because better results contribute to higher revenue. Consequently, these circumstances impede the building of trust between customers and salespersons.

The successful survival of an organization depends on its ability to establish positive and enduring perceptions of mutual trust among its members (Kramer, 2012). Trust is not only important in building long-standing and value-added relationships with external stakeholders; it is a key component in improving internal relationships. At this stage trust can be seen as a social capital that reduces transaction costs, increases spontaneous sociability between members, and encourages effective forms of protection for organizational authorities and also can increase members' organizational citizenship behavior (Ozmen, 2018). Trust is important but more crucial is how to vindicate and repair trust, the effort in activities of building, maintaining, improving and repairing trust is a significant part of every organization, and this is not a very easy and short-term task, this obligation will continue as long as the organization exists. How trustworthiness and trust are updated as a forum to assess successful repair efforts after a negative outcome? (Tomlinson \& Mayer, 2016). An organization needs to adopt an established and appropriate strategy, by doing so the organization can survive, will have a good reputation and strong competitiveness. 
Repairing trust is not just about apology; denial; promises; explanations; accounts; restructuring; penance; compensation; laws, regulations and controls; cultural reforms (Bozic et al., 2019; Jena et al., 2018; Mehta et al., 2020; Tomlinson \& Mayer, 2016), it is recommended to demonstrate reliability, competence, and benevolence continuously and consistently, applications of three types of organizational controls (results, action, personnel controls), and three forms of cooperation (motivate superior-subordinate work coordination, subordinate job engagement, positive interpersonal relationships) (Long, 2018). This strategy is a fundamental step to build and control trust, improve public trust in network marketing organizations with more solid and long-term results. Demonstrating reliability shows that the behavior is guided by principles, promotes justice, values other beliefs, fairness, keeps the word, and consistent actions. Demonstrating competence is about possessing special capabilities that can increase good performance, success while trying to do something, follow direction and gain success, skill, and knowledge to persuade, well qualified and wins the confidence of others. Demonstrating benevolence promotes subordinate or partner interests when getting a chance, communicates respectfulness, keeps others' interests in mind, avoids hurting others and always helping others.

Network marketing organizations' reputation is mostly jeopardized by the unethical practices of the people involved in this industry both consciously and unconsciously. If these years continue and there are no concrete steps to overcome the trust issues, then this industry will eventually fade away and will be drowned. In addressing the issues of trust in addition to government efforts that regulate strictly through establishing regulation and laws, it is very important for every network marketing organization to carry out a strategy for trust repairing, and to do it very seriously and thoroughly. The trust repair issue has been very rarely discussed in previous academic articles where most of the studies examined the issues of abuse, fraud, or violations, only a few articles referred to explore the steps that the organizations must take in dealing with the problems of trust so that it strongly supports the sustainability of the industry.

\section{Conclusions}

Based on the result and discussions, it can be seen that, this study does not emphasize on the problem of violations, fraud and unethical actions that occur in the industry which has been discussed in many academic articles about fraud in network marketing but this study has rather concentrated on efforts and strategic solutions for network marketing organizations to take concrete steps in overcoming trust issues by recommending the model of trust repair proposed by Long (2018). It can be concluded that by implementing this trust repair model consistently and with a full commitment, it can gradually restore people's trust in network marketing industry, sustainable industry existence and exalted purpose of this industry can be achieved.

Suggestion for future research is that it should closely analyze the specific obstacles and opportunities faced by the organization in encouraging team cooperation and building successful working relationships and by exploring how the implementation of controls and displays of trustworthiness has a reciprocal impact on a number of significant subordinate attitudes and behaviors in network marketing industry.

\section{References}

Attri, R., \& Chaturvedi, S. (2011). A Study of Consumer Perceptions of the Products Sold Through Multilevel Marketing. Prabandhan \& Taqniki, Management Research Journal, 5(4), 97-103.

Bosley, S., \& McKeage, K. K. (2015). Multilevel marketing diffusion and the risk of pyramid scheme activity: The case of fortune hi-tech marketing in montana. Journal of Public Policy and Marketing, 34(1), 84-102. https://doi.org/10.1509/ jppm.13.086

Bozic, B., Siebert, S., \& Martin, G. (2019). A strategic action fields perspective on organizational trust repair. European Management Journal, 37(1), 58-66. https://doi.org/10.1016/j. emj.2018.04.005

Chonko, L. B., Wotruba, T. R., \& Loe, T. W. (2002). Direct selling ethics at the top: An industry audit and status report. Journal of Personal Selling and Sales Management, 22(2), 87-95. https:// doi.org/10.1080/08853134.2002.10754297

Constantin, C. (2009). Multi-Level Marketing:A Tool of Relationship Marketing. Economic Sciences, 2(51), 6.

Firman, A., Putra, A. H. P. K., Mustapa, Z., \& Ilyas, G. B. (2020). Re-conceptualization of Business Model for Marketing Nowadays: Theory and Implications. Journal of Asian Finance, Economics, and Business, 7(7), 279-291. https://doi. org/10.13106/jafeb.2020.vol7.no7.279

Häkkinen, S. (2012). Towards a Trust-Based Model of Leadership Within the Leader- Member Exchange Theory Framework (Issue September).

Herbig, P., \& Yelkur, R. (1997). A review of the multilevel marketing phenomenon. Journal of Marketing Channels, 6(1), 17-33. https://doi.org/10.1300/J049v06n01_02

Hurley, R. F., Gillespie, N., Ferrin, D. L., \& Dietz, G. (2013). Designing Trustworthy Organizations. 54(4), 74-82.

Ivashkova, N., Sidorchuk, R., \& Skorobogatykh, I. (2018). Studying distributor-consultants' involvement into MLM business in the russian perfume and cosmetics market. Espacios, 39(33).

Jena, L. K., Pradhan, S., \& Panigrahy, N. P. (2018). Pursuit of organisational trust: Role of employee engagement, psychological well-being and transformational leadership. 
Asia Pacific Management Review, 23(3), 227-234. https://doi. org/10.1016/j.apmrv.2017.11.001

Keep, W. W., \& Nat, P. J. V. (2014). Multilevel marketing and pyramid schemes in the United States: An historical analysis. Journal of Historical Research in Marketing, 6(2), 188-210. https://doi.org/10.1108/JHRM-01-2014-0002

Koehn, D. (2001). Ethical issues connected with multi-level marketing schemes. Journal of Business Ethics. https://doi. org/10.1023/A:1006463430130

Koroth, D. A. A. (2012). Significance of Relationship in Multilevel Marketing and its effect on Business Outcome. IOSR Journal of Business and Management, 3(6), 26-36. https://doi. org/10.9790/487x-0362636

Kramer, R. (2012). Creating more trusting and trustworthy organizations: Exploring the foundations and benefits of presumptive trust. In: Public Trust in Business (Issue 1). https:// doi.org/10.1017/CBO9781139152389.011

Lee, J. W., \& Kwag, M. (2017). Corporate Marketing Strategy Using Social Media: A Case Study of the Ritz-Carlton Seoul. Journal of Asian Finance, Economics and Business, 4(1), 79-86. https://doi.org/10.13106/jafeb.2017.vol4.no1.79

Lee, J. W., Kwag, M., \& Potluri, R. M. (2015). Antecedents of Acceptance of Social Networking Sites in Retail Franchise and Restaurant Businesses. Journal of Asian Finance, Economics and Business, 2(1), 29-36. https://doi.org/10.13106/jafeb.2015. vol2.no1.29.

Lee, K. F., \& Loi, K. Y. (2016). Towards Satisfying Distributors in Multilevel Marketing Companies. International Journal of Management and Applied Research, 3(1), 48-64. https://doi. org/10.18646/2056.31.16-004

Long, C. P. (2018). To control and build trust: How managers use organizational controls and trust-building activities to motivate subordinate cooperation. Accounting, Organizations and Society, 70, 69-91. https://doi.org/10.1016/j.aos.2018. 05.006

Mathews, G. K., Manalel, J., \& Zacharias, S. (2007). Network Marketing: Exploitation of relationships-Myth or Reality? International Marketing Conference on Marketing \& Society, 1989, 159-163.

Mehta, A. M., Tam, L., Greer, D. A., \& Letheren, K. (2020). Before crisis: How near-miss affects organizational trust and industry transference in emerging industries. Public Relations Review, January, 101886. https://doi.org/10.1016/j. pubrev.2020.101886

Merrilees, B., \& Miller, D. (1999). Direct Selling in the West and East The Relative Roles of Product and Relationship (Guanxi) Drivers. Journal of Business Research, 45(3), 267-273. https:// doi.org/10.1016/S0148-2963(97)00238-5

Möllering, G., Bachmann, R., \& Hee Lee, S. (2004). Introduction: Understanding organizational trust: Foundations, constellations, andissues ofoperationalisation.JournalofManagerialPsychology, 19(6), 556-570. https://doi.org/10.1108/02683940410551480

Moradi, M., Bavi, A., \& Ahamd Pooran, J. (2013). Evaluation of Pyramid and Network Marketing. 5(September), 310-316.

Msweli, P., \& Sargeant, A. (2001). Modelling distributor retention in network marketing organisations. Marketing Intelligence \& Planning, 19(7), 507-514. https://doi.org/10.1108/EUM000000 0006215

Muncy, J. A. (2004). Ethical Issues in Multilevel Marketing: Is It A Legitimate Business or Just Another Pyramid Scheme? Marketing Education Review, 14(December 2004), 47-53.

Nurlanova, N. K., Omarov, A. K., \& Satpayeva, Z. T. (2020). Methodological approaches to estimation of economic growth and sustainable development: Kazakhstan's experience. Journal of Asian Finance, Economics and Business, 7(4), 317-324. https://doi.org/10.13106/jafeb.2020.vol7.no4.317

Ozmen, Y. S. (2018). How employees define organisational trust: analysing employee trust in organisation. Journal of Global Responsibility, 9(1), 21-40. https://doi.org/10.1108/jgr-042017-0025

Tham, K.W., Dastane, O., \& Johari, Z. (2019). Perceived Risk Factors Affecting Consumers' Online Shopping Behaviour. Journal of Asian Finance, Economics and Business, 6(4), 246-260. https://doi.org/10.13106/jafeb.2019.vol6.no4.249

Poon, P., Albaum, G., \& Chan, P. S. F. (2012). Managing trust in direct selling relationships. Marketing Intelligence and Planning. https://doi.org/10.1108/02634501211251070

Reingewerts, Y. (2016). An Economic Model of Multi-Level Marketing. Mlm, 1-32.

Salciuviene, L., Reardon, J., \& Auruskeviciene, V. (2011). Antecedents of performance of multi-level channels in transitional economies. Baltic Journal of Management, 6(1), 89-104. https://doi.org/10.1108/17465261111100914

Sreekumar, P. (2007). A Study Of Multi-Level Marketing (MLM), As A Potential Tool For Socio-Economic Development. Mlm.

Sugiyono. (2016). Metode Penelitian dan Pengembangan (Research and Development/R\&D). In Bandung: Alfabeta. https://doi. org/10.1016/j.drudis.2010.11.005

Tomlinson, E. C., \& Mayer, R. C. (2016). The role of causal attribution dimensions in trust repair. The Academy of Management Review, 34(1), 85-104. https://doi. org/10.2307/27759987

Tyler, T. R. (2003). Trust within organisations. Personnel Review, 32(5), 556-568+673. https://doi.org/10.1108/004834803104 88333

Vander N. P. J., \& Keep, W. W. (2002). Marketing fraud: An approach for differentiating multilevel marketing from pyramid schemes. Journal of Public Policy and Marketing, 21(1), 139-151. https://doi.org/10.1509/jppm.21.1.139.17603 